\title{
OSREDOTOČENA INTERAKCIJA V IZOBRAŽEVANJU ODRASLIH Pedagogika ali terapija
}

\section{POVZETEK}

Prispevek obravnava pedagoški koncept na temo osredotočene interakcije avtorice Ruth Cohn. Izhaja iz humanistične psihologije, uvršamo ga pod humanistično pedagogiko. Opisani so nastanek, razvoj in definicija koncepta. Podrobneje sta pojasnjeni didaktika in metodika s poudarkom na vlogi vodje in pedagoške interakcije v procesu pridobivanja znanja. Prispevek prepletajo misli o odnosu in razlikah med pedagogiko in terapijo ter o možnostih uporabe koncepta $v$ izobraževanju odraslih.

Ključne besede: humanistična psihologija, humanistična pedagogika, na temo osredotočena interakcija, pedagogika, terapija

$\mathrm{N}_{2}$ menzentrierte Interaktion «, TZI) je razvila Ruth Cohn s sodelavci na inštitutu »Workshop Institute for Living Learning « in je namenjena učenju posameznika znotraj skupine. Gre za iskanje ravnotežja med temo, posameznikom in skupino. Metoda prevzema bistvena načela »gestalt terapije« in izhaja iz eksperimentalizma in humanistične psihologije, pri čemer Ruth Cohn kot psihoanalitičarka vključi tudi psihoanalitični pristop. Pristop na temo osredotočene interakcije je bil uveden $\mathrm{v}$ šole in izobraževanje odraslih, posebno še pri poklicih s področja nege, sociale in vzgoje ter je najbolj razširjen v nemškem prostoru (Petzold, 1977).

Nasprotje med na posameznika usmerjenim, življenjskim in napetim terapevtskim modelom ter pogosto mrtvim, napornim stvarnim poukom je Cohnovo pripeljalo do prepričanja, da je možna povezava med osebnostno pomembnim in stvarnim učenjem. Koncept naj bi deloval pedagoško-terapevtsko, in sicer ne toliko v zdravilnem psihoterapevtskem pomenu, temveč v smislu skrbnega povečevanja kontakta posameznikov $\mathrm{z}$ njihovimi lastnimi notranjimi močmi, z drugimi osebami, temo in nalogami, s katerimi se srečujejo v vsakdanjem življenju (Sielert, 1995).

Razlaga načel na temo osredotočene interakcije nam omogoča vpogled v ta, na svoj način izjemen pedagoško-terapevtski koncept.

\section{DEFINICIJA IN NAČELA NA TEMO OSREDOTOČENE INTERAKCIJE}

»Osredotočena interakcijska metoda je povezava učenja snovi in spodbujanje razvoja osebnosti« (Cohn v Vopel, 1977, str. 89). S tem sta nekako pokriti obe področji oz. oba vira skupinskega dogajanja: pedagoška tradicija in terapevtsko področje. Iz pedagoške tradicije izvira spoštovanje teme, ki določa 
nalogo skupine in na ta način koncentrira emocionalno in intelektualno energijo udeležencev. Iz terapevtskega področja pa izvira poudarjanje interakcije, in sicer $v$ notranjosti terakcija za spodbujanje razvoja osebnosti.
Osredotočena invsakega posameznika kot komunikacijski proces med različnimi osebnostnimi elementi in tudi znotraj skupine kot komunikacijski proces med različnimi člani skupine (Vopel, 1977).

Sistematika na temo osredotočene interakcije izhaja teoretično iz treh aksiomov, ki formulirajo probleme kot »nasprotujoče si celote« in so označeni kot pogoji oz. temelji. V nasprotju z lingvistično uporabo pa ti aksiomi ne pomenijo neke absolutne resnice:

- Eksistencialistično antropološki aksiom: človek je pojmovan kot psihobiološka enota in del univerzuma. Človek je avtonomen in odvisen od drugih ljudi.

- Filozofsko etični aksiom: spoštovanje rasti/ razvoja pogojuje ovrednotene odločitve.

- Pragmatično politični aksiom: svobodna odločitev se zgodi znotraj in zunaj pogojenih meja. Širjenje teh meja je mogoče. Svoboda pri odločanju je večja, če smo zdravi, inteligentni, duhovno razviti in nimamo materialnih problemov, kot če smo bolni, omejeni, revni, trpimo zaradi nasilja ali nismo dovolj zreli (Matzdorf/Cohn v Karmann, 1987).

Cilji, ki naj bi jih z metodo osredotočene interakcije dosegli, so:

- celostno učenje $\mathrm{z}$ uravnoteženim vključevanjem osebnosti (jaz), skupine (mi) in teme/stvari (ono),

- širinska/splošna terapija trenutnih motenj, ki ni in ne more biti nadomestek za psihoterapijo,

- preventiva in preprečevanje duševno-telesno-duhovnega neravnotežja in spodbujanje organsko-psihične rasti,

- zavedanje, razumljeno kot proces,

- orientacija, razumljena v smislu humanejšega življenja v svetu (Karmann, 1987, str. 201-203).
Prepletenost nasprotujoče celote je značilna za celoten sistem na temo osredotočene interakcije: bližina in distanca, omejevanje in približevanje, notranja in zunanja perspektiva, orientiranost na subjekt in na realnost niso obravnavani kot različni konci enodimenzionalne linije, temveč kot nasprotja, ki se pogojujejo in sodijo skupaj (Reiser, Lotz, 1995).

\section{PEDAGOŠKI CILJI}

$\mathrm{Na}$ področju teorije pedagogike na temo osredotočene interakcije obstajata dve vrsti orientacije, in sicer glede načina mišljenja in glede vsebin. Pri načinu mišljenja se poudarja dialektično enost nasprotij in spreminjanje perspektiv. Ponujene vsebine so ozaveščanje, nujnost osebnih vrednotnih odločitev in širjenje notranjih in zunanjih meja. Karakteristika vsebin je optimistična tendenca, s pomočjo katere je možno uresničevanje vsebin (Reiser, Lotz, 1995).

$\mathrm{Na}$ temo osredotočeno interakcijo razumemo kot pedagoško-terapevtski in hkrati kot družbeno-terapevtski pristop. V pedagoškem procesu - ne glede na to, ali je to $v$ šoli, organizaciji ali $v$ znanosti - je običajno $v$ ospredju naloga posredovati znanje, teme pouka, pravila in drugo, namen je torej posredovati neko temo. Pri osredotočeni interakciji pa gre za subjektivizacijo teme in spodbujanje zmožnosti interakcije teme. Za oživitev učnih procesov na temo osredotočene interakcije je potrebna uporaba celostnega znanja s področja humanističnih ved, predvsem psihologije, psihoterapije in komunikacijskih znanosti. V pripravi pouka je pomembno najti teme, ki so trenutno udeležencem pomembne, in jim na ta način posredovati tematiko, povezano z okolico, s svetom (Sielert, 1995). Učni cilj je, da vsak posameznik najde svoj individualen odnos, povezavo $\mathrm{z}$ določeno temo, kar je mogoče v zavestnem skupnem delu z ostalimi udeleženci. 


\section{JIDAKTIKA IN METODIKA}

)idaktični koncepti in metodika na temo osreotočene interakcije temeljijo na vzpostavanju ravnotežja med dejavniki jaz, mi, ono tema), na definiranju in predstavitvi teme, na ostulatih in pomožnih pravilih kot posledici spešne komunikacije. Dinamični trikotnik z ejavniki jaz, mi, ono (tema) predstavlja bližjo in daljno okolico, v kateri se interaktivna kupina srečuje. Praktični temelj vsake takšne kupine so odnosi med temi tremi točkami. Ja prvi pogled enostavna struktura omogoča realnosti neverjetno veliko možnosti in tudi evarnosti $v$ smislu razvoja že obstoječega otenciala rasti.

'ri tem gre za poskus, da bi filozofska načela umanistične miselnosti uporabili s pomočjo sihološke didaktike. Cohnova (v Quitmann, 996) kot izraz temeljnega filozofskega pritopa navaja dva eksistencialna postulata:

1. Bodi sam svoj vodja.

2. Motnje imajo prednost.

'rvi poudarja odgovornost posameznika in pomembnost lastnih vrednot. $\mathrm{K}$ temu osebnemu svetu spada tudi sposobnost zaznavanja in sprejemanja lastnih občutkov, misli in telesa. Zavedanje pričakovanj, ki izhajajo iz teh področij, ne pomeni njihove avtomatične zadovoljitve, temveč gre $\mathrm{za}$ odločitve glede njih in za te odločitve je odgovoren posameznik. Pomembno je resno jemanje sebe, drugih in naloge. Biti samemu sebi vodja pomeni torej dojemanje možnosti in omejitev sebe kot čloOsredotočena interakcija zahteva, da je vsak sam svoj vodja. veškega bitja, človeško bitje pa je odvisno od izmenjave $\mathrm{z}$ okoljem, od dajanja in prejemanja in le človek sam je odgovoren, koliko in kaj daje ter prejema (Quitmann, 1996). Poudarjena je torej sposobnost zaznavanja in lastna odgovornost.

Drugi postulat pomeni upoštevanje ovir, lastnih in tistih, s katerimi se soočajo drugi. Pojmovanje motenj je izpeljano iz razumevanja in izkušenj Cohnove, da se dolgočasje, pomanjkanje koncentracije in izguba pozornosti

Pomožna pravila podpirajo postavitev ciljev in strukturirajo komunikacijsko raven.

Quitmann (1996, str. 202-204) jih povzema v šestih točkah:

1.Zastopaj samega sebe v svojih izjavah, govori o »jaz« in ne »mi«, kar pomeni izogibanje splošnim frazam; način omogoča prevzem odgovornosti za povedano.

2. Kadar postaviš vprašanje, povej, zakaj sprašuješ in kaj tebi pomeni vprašanje. Bolje je sicer izraziti lastno mnenje, izjavo o nečem, vprašanja namreč lahko včasih postanejo neke vrste igra/boj, izogibanje konkretnemu ali lastnim izkušnjam in spoznavanju.

3. Kadar le moreš, ne interpretiraj drugih. Namesto tega izrazi lastne osebne reakcije. Interpretacija vedenja drugih ljudi je smiselna le takrat, kadar je zanjo zaprošeno, sicer lahko vzbudi odpor in le redko spodbuja medsebojne odnose.

4.»Motnje imajo prednost« je tako postulat kot pravilo. Vsak udeleženec ima možnost, da prekine pogovor, kadar ga res ne more več poslušati, se ga udeleževati. Tema se v tistem trenutku zamenja. Nadaljuje se šele takrat, ko je motnja udeleženca razjasnjena in lahko ponovno sodeluje pri pogovoru.

5.Paziti je treba na to, da ima besedo vedno le en udeleženec, da ga nihče ne prekinja in ga vodja posluša. Pogosto pride do tega, da želi več udeležencev hkrati govoriti. Edina rešitev je, da se udeleženci učijo paziti povedati tisto, kar jim je pomembno, in hkrati vzamejo resno, kar povedo drugi. Kdo bo govoril, tako ne odloča vodja, temveč vsak posameznik, gre za lastno odgovornost.

6. Opazuj znake lastnega telesa in opazuj jih tudi pri drugih. S tem pravilom vzpostavi Cohnova protiutež zanemarjanju telesa v delovnih skupinah. Zaznavanje telesa in čustev se aktivira kot pomemben dejavnik v delovanju skupine. 
pokažejo npr. kot govorjenje med učno uro, delanje hrupa, izguba pozornosti, simpatija ali antipatija do drugega člana skupine, fenomeni realnosti, ki jih moramo zaznati in sprejeti, kajti le tako se pokaže možnost in odgovornost za njihovo spremembo. Govori tudi o zmoti psihoanalize glede transfera in kontratransfera: $\mathrm{z}$ zavestno ojačitvijo transfera naj bi omogočili boljšo razrešitev konflikta. Strinja se s psihodramatiki, »gestalt terapevti « v smislu takojšnega in neposrednega soočenja in obdelave simptomov transfera namesto vnaprejšnje ojačitve in nato reševanja tega (Quitmann, 1996). Tu ne gre le za motnje, ki nastanejo v skupini med udeleženci, temveč tudi za konflikte, ki jih posameznik odkrije znotraj sebe. Gre za zavedanje in poslušanje lastnih nasprotujočih si glasov in dajanje prednosti enemu ali drugemu. Kadar je udeležencem dana možnost za zavedanje notranjih konfliktov, jih ti tudi lažje razrešijo. Glede na skupinsko interakcijo to pomeni, da ima vsak udeleženec možnost, da kadarkoli prekine delo skupine, če ne more več sodelovati, in izrazi, kaj ga moti. Motnja je nato v središču skupinske diskusije toliko časa, da se lahko udeleženec ponovno vključi v aktivnosti skupine. Čas, ki ga tak proces zahteva, se navadno izravna $z$ bistveno močnejšo skupinsko strukturo, povezanostjo in delovno zmožnostjo celotne skupine (Vopel, 1977).

\section{VLOGA VODJE IN PEDAGOŠKA INTERAKCIJA}

Vodja skupine na temo osredotočene interakcije ima nalogo, da skrbi za dinamično ravnotežje v komunikacijskem procesu in za upoštevanje pomožnih pravil. Njegovo strokovno znanje je za skupino pomembno, hkrati pa on ne prevzame celotne odgovornosti za učni proces. Značilno za voditelja je, da so njegova mnenja in odnos ter vedenje za učni in delovni proces skupine pomembna prav tako kot način, na katerega tehnično usmerja skupino, in način, kako upravlja s konceptualnimi ele- menti metode. Pri tem imata poseben pomen pristnost vodje $\mathrm{v}$ njegovi funkciji in pristnost njegove osebnosti. Vodja se zaveda svojega počutja in čustev, jih prepoznava, sprejme sebe in na ta način lahko sprejme ter spoštuje tudi ostale udeležence, jim zaupa in na primeren način tudi posreduje svoja čustva. Cohnova (v Vopel, 1977, str. 94) se izreče proti klasični analitični drži, pri kateri tiho opazovanje in analitične intervencije $v$ udeležencu vzbujajo občutek nemočnega otroka. Nevtralni vodja ima na ta način večjo transferno moč in kljub njegovi nejasnosti bi morali udeleženci ugotoviti, kakšna oseba je, kakšne motive in cilje ima, kaj si misli. Nasprotno pa je pristnost zagotovo temeljni pogoj za vodje skupin. Naslednja pomembna kvaliteta vodje je empatija, sposobnost za razumevanje reakcij in ravnanja drugih. Bolj kot je sposoben empatije, lažje mu je vzpostavljati ravnotežje med dejavniki.

V ospredju sta dve kvaliteti, in sicer permisivnost in interdependenca, ki izhajata iz spoštovanja obeh postulatov. Permisivnost v tem primeru pomeni dati udeležencem toliko svobode, kot je mogoče, da določijo svoje učne cilje, da ravnajo ustrezno svoji učni motivaciji in sami odločajo o strategijah za učenje. Permisivnost pomeni tudi spodbujanje udeležencev k samostojnemu ravnanju in skupnemu načrtovanju, sproščenost v stresnih situacijah, ko skupini ne gre dobro ali kadar nastopijo konflikti. Interdependenca, vzajemna odvisnost, je poskus uravnoteženja potrebe po moči vodje in želja udeležencev po samostojnosti. Voditelj skupaj z udeleženci išče cilje in rešuje probleme. Lastno avtoriteto razume kot funkcionalno, $\mathrm{z}$ jasno komunikacijo zmanjšuje procese transfera ter s svojo emocionalno in intelektualno prisotnostjo pomaga udeležencem, da ugotovijo, kaj delajo, na kakšen način in česa si želijo (Vopel, 1977).

Izziv za vodjo predstavljajo nevarnosti, lahko npr. nastane skupina, v kateri so konflikti »tiho« nezaželeni, tako da udeleženci ne morejo razviti resnične bližine, saj med njimi 
str. 205). Razlika je pomembna zato, ker naj bi bil ta koncept v prvi vrsti koncept za »življenjsko učenje« v šolskih razredih, bolnišnicah, univerzah, podjetjih ter upravi; glavni cilj torej ni bil predelava nepredelanih situacij iz preteklosti, ampak osredotočenost na spreminjanje sedanjosti. Zato je v središču interakcijske skupine tema; $v$ šolskih razredih je ta običajno vzeta iz učnega načrta, v drugih skupinah je včasih iskanje teme del prvega delovnega koraka. S tem, da je tema postavljena v središče skupine, okoli katere sta povezana jaz in mi, je seveda možno oblikovati temo, delo na njej v okviru spoznavanja/doživljanja samega sebe in tako nastane terapevtska skupina. 
Za učitelje na temo osredotočene interakcije je pomembno zavedanje meja med terapijo in pedagogiko, učna situacija učenja in poučevanja je definirana pedagoško-didaktično in ne terapevtsko, prav tako so cilji vodij ali učiteljev usmerjeni v posredovanje nekih vsebin in sposobnosti zdravim ter niso namenjeni zdravljenju bolnih. Pomembno je seveda prepoznavanje motenj in odgovarjajoče usmerjanje ter napotitev udeležencev s takšnimi problemi v ustrezne terapevtske institucije.

Ob uporabi postulata »motnje imajo prednost « se pojavijo motnje in konflikti znotraj skupine ali posameznikov, zato lahko rečemo, da si nekako tudi same vzamejo prednost, saj gre ob tem ponavadi za emocionalno močne vsebine. Te motnje so obravnavane kot ovire ali odkloni, ki onemogočajo osredotočenje skupine na določeno temo. Konkretnih primerov

Kje je meja med pedagoškim in terapevtskim delom? delovanja takšne strategije ob zdolgočasenosti, pomanjkanju motivacije in agresivnosti nam literatura ne ponuja, le vedno znova se osredotoči na samega vodjo, ki naj bi se spraševal tudi, ali je tema, ki jo obravnava, primerna, ali je predstavljena na primeren način, kakšen je njegov odnos do udeležencev, do teme in podobno.

\section{ZAKLJUČEK}

Vsekakor ne moremo mimo vprašanja, ali je praksa takšnega koncepta možna $\mathrm{v}$ šolskem okolju, kjer učenci ne morejo sami izbirati vsebin, kjer morda $v$ času pubertete niso naklonjeni priznavanju, obravnavanju in odpravljanju svojih pomanjkljivosti, kjer verjetno vsaka uporaba nove metode prinese le dodaten stres. Kje je meja med pedagoškim in terapevtskim delom in na kakšen način se je možno izogniti manipulacijam vodje in zlorabi koncepta? Vsekakor je uporaba koncepta primernejša za izobraževanje odraslih, $\mathrm{v}$ prostovoljnem in dovolj odprtem okolju, ki omogoča odražanje pozitivnih učinkov tega koncepta.

Če gledamo na koncept na temo osredotočene interakcije kot na vrsto pedagogike, ki jo je možno primerjati z drugimi, ji v prid govori dejstvo, da vsebuje temeljne elemente pedagogike, kot je npr. vizija vrednot, ki naj bi bile realizirane $v$ vzgojnem procesu. Na temo osredotočena interakcija ponuja okvir pravil za vedenje v skupini in vodenje, teh pravil se je možno naučiti in so del izobraževanja ter usposabljanja vodij in učiteljev na temo osredotočenih interakcijskih skupin. Znotraj okvira, ki ni vedno togo upoštevan, je prostor za dinamični trikotnik: jaz, mi in ono (tema). Z interakcijo med temi tremi dejavniki in upoštevanjem zunanjega dejavnika, ki se navezuje na svet in na globalno, so odprte možnosti za malo drugačen, učinkovit način pridobivanja določenih znanj in sposobnosti v skupinskem izobraževanju odraslih. Na temo osredotočena interakcija $v$ našem prostoru, razen nekaj iz tujine prenesenih seminarjev $v$ podjetjih, $v$ glavnem ni poznana. Morda prav zato - kljub temu, da je nastala že konec šestdesetih let - za nas predstavlja nekaj novega in odpira nove možnosti uporabe $\mathrm{v}$ izobraževanju in usposabljanju odraslih.

\section{LITERATURA}

Karmann, G. (1987). Humanistische Psychologie und Pädagogik. Bad Heilbrunn: Verlag Julius Klinkhardt.

Petzold, H. G. (1977). Gestaltpädagogik. V: Petzold, H. G., Brown, G. I. (ur.). Gestalt-pädagogik. Konzepte der Integrativen Erziehung. München: Verlag J.Pfeiffer, str. 7-13.

Quitmann, H. (1996). Humanistische Psychologie. Göttingen-Bern-Toronto-Seattle: Hogrefe, Verlag für Psychologie.

Reiser, H., Lotz, W. (1995). Themenzentrierte Interaktion als Pädagogik. Mainz: Matthias-Grünewald-Verlag. Sielert, U. (1995). Themenzentrierte Interaktion nach Ruth Cohn (TZI). V: Buddrus, V. (ur.). Humanistische 
Pädagogik. Bad Heilbrunn: Verlag Julius Klinkhardt, str. 249-265.

Vopel, K. W. (1977). Lernen zwischen Thema und Interaktion. Die Themenzentrierte Interaktion nach Ruth $C$. Cohn. V: Petzold, H. G., Brown, G. I. (ur.). Gestalt-pädagogik. Konzepte der Integrativen Erziehung. München: Verlag J. Pfeiffer, str. 88-100. 